\title{
AN INDIGENOUS PACIFIC HUMAN RiGHTS MECHANISM: SOME BUILDING BLOCKS
}

\author{
Valmaine Toki* ${ }^{*}$ and Natalie Baird ${ }^{* *}$
}

\begin{abstract}
This article explores the possibility of a Pacific regional human rights mechanism, in particular in regard to how the rights contained in such a mechanism should be framed. It provides a case study of the New Zealand seabed and foreshore legislation and its impact in New Zealand as well as the CERD Committee's reaction to the challenge to that legislation. Secondly, the article using the case study as a starting point, discusses the importance of an indigenous "lens" to develop the composition of rights in a Pacific regional mechanism.
\end{abstract}

\section{INTRODUCTION}

As Pacific peoples ${ }^{1}$ we are defined by our culture and our custom. Wickliffe states: ${ }^{2}$

No one can ignore the central role culture plays in determining the way people in the Pacific relate to each other and their communities ... it reflects the values and norms of Pacific societies ... it can either assist or hinder the promotion and protection of human rights.

The exact composition and requirements of a Pacific regional human rights mechanism (PRM) are unclear and remain to be developed in the months and years ahead. However, human rights experts suggest that any such mechanism must be underpinned by universal human rights; rights

* Lecturer in Law, Law Faculty, University of Auckland.

** Lecturer in Law, Law Faculty, University of Canterbury.

1 "Pacific peoples" in this paper refers to the people of the sixteen member states of the Pacific Islands Forum: Australia, Cook Islands, Federated States of Micronesia, Fiji Islands, Kiribati, Nauru, New Zealand, Niue, Papua New Guinea, Republic of Marshall Islands, Samoa, Solomon Islands, Tonga, Tuvalu and Vanuatu.

2 C Wickliffe "An Overview of Human Rights Developments in the Pacific Region with an Emphasis on the Collective Right to Self Determination" in N Tomas (ed) Collective Human Rights of Pacific Peoples (International Research Unit for Māori and Indigenous Education, University of Auckland, Auckland, 1998) 168. 
that are identified in the Universal Declaration of Human Rights 1948 (UDHR) ${ }^{3}$ and other international standards. ${ }^{4}$ These universal rights would inform the content of the PRM. Although it is envisaged that universal human rights are to be a floor rather than a ceiling, ${ }^{5}$ this creates a challenge for Pacific peoples, as universal human rights standards are not sourced from custom, but primarily from Western values. Inevitably a tension arises between maintaining local values and customs and implementing universal human rights. This will be a significant challenge to be met in developing a PRM. Ultimately, for the PRM to be culturally legitimate, robust and viable in the long term, it must reflect the wisdom of both custom and human rights.

This article focuses on two sets of issues - procedural and substantive - that, in our opinion, are important with respect to the viability and robustness of the PRM. Part I addresses two preliminary matters of context. We begin with a case study of a recent New Zealand experience with some of the mechanisms of the international human rights framework. This case study informs our subsequent analysis and assessment of what we think are some of the important elements to be included in the PRM. In order to set the issues in their theoretical context, we then look briefly at the debate between universalism and cultural relativism.

Parts II and III look at the two sets of "building blocks" which we see as essential in developing a culturally legitimate, robust and viable PRM. Part II looks at the first set of issues - the processes and procedures involved with developing a mechanism. First, we suggest that an indigenous starting point is required so that other issues important to a Pacific understanding and application of human rights are considered. Following on from this, we make some suggestions about the need for wide participation in the development of the PRM. We address the importance of human rights education, both as the PRM is developed and once it is up and running. Part III of the article considers a second set of building blocks that are more concerned with the substantive content of the PRM. We consider three matters which are likely to require inclusion in the PRM itself. These are group rights in addition to individual rights, the possibility of individual duties alongside rights, and whether decisions of the PRM should be binding.

\section{CONTEXT}

\section{A A Salutary Case Study: Foreshore and Seabed in Aotearoa New Zealand}

Before setting out our suggestions for a PRM, we begin with what we think is a salutary case study of both the promise and pitfalls of the international human rights framework. This case study

3 Universal Declaration of Human Rights (10 December 1948) UN Doc GA/Res/217A (III) [UDHR].

$4 \quad$ P I Jalal "Why Do We Need a Pacific Regional Human Rights Commission?" in this volume.

5 K Boyle "The European Experience" (Strategies for the Future: Protecting Rights in the Pacific, Apia, 27-29 April 2008) oral comments. 
has directly informed our analysis and assessment of what we think are important elements to be considered in any PRM.

In New Zealand, despite intense national opposition to the Foreshore and Seabed Bill, Parliament passed legislation in 2004 vesting the foreshore and seabed in the Crown. The strongest grounds for challenging the Foreshore and Seabed Act 2004 (FSA) lay in the right to freedom from discrimination. New Zealand is a party to the International Convention on the Elimination of All Forms of Racial Discrimination (CERD). ${ }^{6}$ Te Runanga o Ngai Tahu asked the United Nations Committee on the Elimination of Racial Discrimination (the CERD Committee), to consider the FSA against New Zealand's obligations under CERD. The CERD Committee issued a report in March 2005. ${ }^{7}$

The CERD Committee reviewed the compatibility of the FSA with the provisions of CERD in the light of information received from both the Government of New Zealand and a number of nongovernmental organisations, and taking into account its general recommendation No. XXIII on indigenous peoples. In noting the political atmosphere, the haste with which the legislation was enacted, insufficient consideration to alternative responses which might have accommodated Māori rights within a framework more acceptable to Māori and other New Zealanders, and the scale of opposition, the CERD Committee stated that the foreshore and seabed legislation, on balance, discriminated against Māori by extinguishing the possibility of establishing Māori customary title over the foreshore and seabed, and by failing to provide a guaranteed right of redress. ${ }^{8}$ The Committee suggested that the Crown resume dialogue with Māori and try to find ways of lessening the discriminatory effects of the FSA, including where necessary through legislative amendment. ${ }^{9}$

However, the New Zealand Government (and most other political parties except the Māori Party and the Green Party) dismissed the report. The Government belittled the report by suggesting it was unimportant and the CERD Committee did not really understand the complexity of the issue. It was also suggested that even if there were some "discriminatory aspects" in the FSA, this did not

6 International Convention on the Elimination of all forms of Racial Discrimination (21 December 1965) 660 UNTS 195.

7 Committee on the Elimination of All Forms of Racial Discrimination "Decision 1 (66): New Zealand Foreshore and Seabed Act 2004" (11 March 2005) CERD/C/66/NZL/Dec.1.

8 Ibid, point 6.

9 For further discussion, see Claire Charters and Andrew Erueti "Report from the inside: the CERD Committee's Review of the Foreshore and Seabed Act 2004" (2005) 36 VUWLR 257; Nin Tomas (ed) Update on Foreshore and Seabed developments since 2004 Editor's note (2007) 2 Te Tai Haruru Journal of Māori Legal Writing 138. 
necessarily mean a breach of CERD; in fact any evidence of discrimination is a breach of international law. ${ }^{10}$ Unsurprisingly, the report did not prompt any change in governmental policy.

In November 2005, following Government criticism of the report issued by the CERD Committee, Professor Stavenhagen, a Mexican researcher, and the United Nations' Special Rapporteur on the Situation of the Human Rights and Fundamental Freedoms of Indigenous Peoples, arrived in New Zealand at the invitation of the Government. His final report was completed in March 2006. ${ }^{11}$ It was highly critical of the Government in a number of areas, including the FSA. The report recommended that the FSA should be repealed or significantly amended.

The Government's response to this further criticism was again negative. It was suggested that Professor Stavenhagen's report was unimportant and did not really address the complexity of the issue. The (then) Deputy Prime Minister, Dr Michael Cullen, claimed that the report was unbalanced without providing any evidence as to what that meant. ${ }^{12}$ Nevertheless, the Stavenhagen Report is the product of the United Nations, the world's most important international human rights institution, and it has become glaringly obvious to the United Nations' top human rights official, the High Commissioner for Human Rights, that New Zealand is in breach of the fundamental laws that it expects its own citizens to uphold. ${ }^{13}$ Moana Jackson argues that "for New Zealand to belittle a report that is the product of the most important international human rights institution there is; is to belittle the very notion of human rights." ${ }^{14}$

The third chapter in this case study was the July - August 2007 review of New Zealand's performance in implementing CERD. The CERD Committee considered New Zealand's $15^{\text {th }}-17^{\text {th }}$ periodic report at its $71^{\text {st }}$ session in Geneva. The Government was required to explain not only its response to the March 2005 CERD report but also answer questions on the status of the Treaty and Māori participation in decision-making. The CERD Committee repeated its previous findings and suggested renewed dialogue between the Crown and Māori about the FSA. However, the Minister of Foreign Affairs dismissed the CERD Committee as "meddlesome." 15

10 Moana Jackson "The United Nations on the Foreshore: A Summary of the Report of the Special Rapporteur" www.converge.org.nz/pma/mj050406.pdf (accessed 16 May 2008).

11 ECOSOC "Report of the Special Rapporteur on the Situation of the Human Rights and Fundamental Freedoms, Mission to New Zealand" (13 March 2006) UN Doc E/CN.4/2006/78/Add.3.

12 Jackson, above n 10.

13 Tomas, above n 9, 139

14 Jackson, above n 10.

15 See comments made by Te Ururoa Flavell, available at www.parliament.nz/enNZ/PB/Debates/Debates/e/6/5/48HansD_20070822_00000769-General-Debate.htm (accessed 16 May 2008). See also www.scoop.co.nz/stories/PA0708/S00387.htm (accessed 16 May 2008). 
This case study highlights a number of issues. A universal human rights approach for Māori, while achieving some success, is ultimately not delivering much in the way of concrete benefits. Although Māori succeeded in accessing international human rights mechanisms, and those mechanisms found in their favour, the actual outcome for Māori was no change to the status quo. A number of questions are raised. Why is the international human rights framework ultimately not delivering for Māori? Does the existing international human rights framework adequately take account of the perspectives and position of indigenous collectives? Has the very framing of human rights somehow excluded the Māori perspective? Does the existing framework allow for sufficient participation by indigenous groups? How viable and robust is the international human rights framework when a state can simply ignore recommendations with impunity? Finally, would a Pacific regional mechanism have ensured a better outcome for Māori in this situation?

\section{B The Theoretical Context: Universalism and Cultural Relativism}

The international human rights movement has, throughout its history, since the adoption of the UDHR in 1948, been plagued by allegations that the way in which human rights are understood and defined is a Western one. This debate, most well known by its universalist and cultural relativist proponents, is part of the underlying context for our subsequent discussion of key procedural and substantive building blocks for the PRM, so we summarise it briefly here.

Those who adopt the universalist viewpoint claim that international human rights like equal protection or free speech must be the same everywhere. This is perpetuated with universal terms contained within human rights treaties such as "everyone has the right," "all persons," "no one". Everyone is entitled to all the rights and freedoms contained in the UDHR irrespective of race, colour, sex, language, religion, political or other opinion. ${ }^{16}$ The text of these basic instruments makes no explicit concession to cultural variation. ${ }^{17}$

Pacific scholar Konai Helu Thaman considers that: ${ }^{18}$

Such assumptions were at best naïve and at worst arrogant, because most international covenants are based on Western liberal beliefs and values, and like all beliefs and values, they are embedded in a particular cultural agenda where indigenous peoples together with their assumptions and values have been and continue to be disregarded and marginalised.

Supporters of the universal application of human rights reject the claim that if human rights norms conflict with cultural practices, the particularity of the culture should take precedence over

16 UDHR, above $\mathrm{n} 3$, art 2.

17 H J Steiner and P Alston International Human Rights in Context: Law, Politics, Morals (Oxford, Clarendon Press, 1996) 193.

18 K H Thaman "Cultural Rights: A Personal Perspective" in M Wilson and P Hunt (eds) Culture, Rights, and Cultural Rights: Perspectives from the South Pacific (Huia Publishers, Wellington, 2000) 1, 3. 
the universal standard. ${ }^{19}$ Universalists claim that an objective yardstick must be used to measure behaviour and allowances should not be made for cultural variation. To think otherwise is said to challenge the validity of human rights (and the belief that all humans are equal and therefore entitled to equal protection) and retard the development of universal standards. ${ }^{20}$

Cultural relativists on the other hand consider that notions of right (and wrong) and moral rules necessarily differ throughout the world because the cultures in which they inhere themselves differ. Human rights depend on a cultural context or a cultural situation or background. Notwithstanding the view that everyone is entitled to basic human rights such as the right to life and to be free from violence, relativists situate human rights in a cultural context.

The cultural relativist holds that human rights norms ought to be subject to culture. ${ }^{21}$ The advocates of cultural relativism claim that rights and rules about morality are encoded in and thus depend on cultural context. The term "culture" is used in a broad and diffuse way that may go beyond indigenous traditions and customary practices to include political and religious ideologies and institutional structures. ${ }^{22}$ Critics of the universal application of human rights challenge the assumption that international human rights should be applied universally on the basis that the perception and valuation of rights is culturally partial, and that practices that are valid according to a particular culture should not be overridden by "outsiders." 23

Cultural relativism challenges the very substance and basis of human rights as a eurocentric approach that ignores the diversity of world cultures. ${ }^{24}$ Universal human rights are seen as reflecting values and norms of Western culture. This is a broad use of the term "culture" beyond indigenous traditions to include political, religious and institutional structures. When the UDHR was adopted in 1948, it was against a very different backdrop which may have limited any reference to collective rights or culture. It was a time where unity and stability were paramount and references to culture could have been perceived as support for culturally fanatical ideologies and group rights such as those perpetrated by Nazism. Equally though, it is significant to note that at the time of its

19 K Johnston "Māori Women Confront Discrimination: Using International Law to Challenge Discrimination" (2005) 4 Indigenous Law Journal 19, 51.

20 Ibid.

21 See for example Ermineskin Cree Nation v Canada (Canadian Human Rights Tribunal) [2001] AJ No 1187 ABQB 760 (QL) where the Sawbridge Indian band totally rejected the application of the Canadian Human Rights Act to its community on the basis that it was unconstitutional to the extent it infringed their Aboriginal treaty rights (self determination).

22 Steiner and Alston, above n 17, 192.

23 C MacKinnon Sex Equality (New York Foundation Press, 2001) 471.

24 R Commaraswamy "Different but Free: Cultural Relativism and Women's Rights a Human Rights" in Courtney W Howland (ed) Religious Fundamentalisms and the Human Rights of Women (St Martins Press, New York, 1999) 79. 
adoption, there were only 56 member states of the United Nations, and large parts of the world, including much of the Pacific, were still colonised.

In recent years however, there has been a convergence of the universalist and cultural relativist camps. For example, the Vienna Declaration 1993 states: $^{25}$

All human rights are universal, indivisible and interdependent and interrelated... While the significance

of national and regional particularities and various historical, cultural and religious backgrounds must be

borne in mind it is the duty of the States regardless of their political, economic and cultural systems, to

promote and protect all human rights and fundamental freedoms.

We support this convergence of views and take a pragmatic approach. We see ourselves as neither universal nor relativist, but culturally pragmatic. Drawing on the ideas of writers such as Abdullahi An Na'im ${ }^{26}$ and Sally Engle Merry, ${ }^{27}$ and endorsing the approach taken by the New Zealand Law Commission, ${ }^{28}$ we instead argue for an approach which seeks to understand, interpret and apply human rights in the Pacific context. We seek an approach that aims, explicitly and unambiguously, to ensure that human rights in the Pacific are "culturally legitimate." 29 This will require drawing on both traditional values and customs and human rights.

\section{PROCEDURAL BUILDING BLOCKS}

\section{A Why Adopt an Indigenous Lens?}

We propose that an indigenous starting-point to develop the composition of rights within the PRM is essential. ${ }^{30}$ It is clear that the international human rights framework has not yet caught the

25 World Conference on Human Rights "Vienna Declaration and Programme of Action" (25 June 1993) A/CONF.157/23 para 5 .

26 See Abdullahi An Na'im (ed) Human Rights in Cross-Cultural Perspectives: Quest for Consensus, (University of Pennsylvania Press, Philadelphia, 1992).

27 See S E Merry "Changing rights, changing culture" in Jane K Cowan, Marie-Benedicte Dembour and Richard A Wilson (eds) Culture and Rights: Anthropological Perspectives (Cambridge University Press, Cambridge, 2001); S E Merry Human Rights and Gender Violence, (University of Chicago Press, Chicago, 2006).

28 New Zealand Law Commission Converging Currents: Custom and Human Rights in the Pacific (Study Paper 17, Law Commission, Wellington, 2006) paras 5.40-5.57.

29 Abdullahi An Na'im uses the language of "cultural legitimacy" and argues for an approach which identifies the lack of cultural support for some human rights and then seeks ways to support and legitimise the particular human rights in terms of the values, norms and processes of the particular culture. See Abdullahi An-Na'im "Problems of Universal Cultural Legitimacy for Human Rights" in Abdullahi Ahmed An-Na'im and Francis M Deng (eds) Human Rights in Africa: Cross-Cultural Perspectives (The Brookings Institution, Washington, DC, 1990) 331, 339.

30 Throughout this paper we use the term "indigenous." While it was tempting to attempt an explanation of our use of this term, this would be a separate article in itself, and we have not attempted an abbreviated version 
"hearts and minds" of Pacific Island Countries and Territories (PICTs). Tony Angelo once suggested that in the Pacific islands human rights is an alien concept, born substantially from the Western European political experience as a development of a European notion of law. ${ }^{31}$ This may be reflected by the reluctance of some PICTs to sign up to and ratify international human rights treaties such as the International Covenant on Civil and Political Rights ${ }^{32}$ and the International Covenant on Economic, Social and Cultural Rights. ${ }^{33}$ From the Pacific island members of the Pacific Islands Forum, only the Cook Islands, Niue, Papua New Guinea and the Solomon Islands are party to ICESCR; and the Cook Islands, Niue, Papua New Guinea, Samoa and Vanuatu are party to ICCPR.

The expectation for PICTs to sign and ratify international human rights covenants is seen by Thaman $^{34}$ as yet another form of external intervention when Pacific peoples are already reeling from a suffocating Western, and perhaps more recently Eastern, ${ }^{35}$ economic domination. The low level of PICT engagement with the international human rights framework suggests that the PRM should not simply be a Pacific reflection of the international framework. To be a robust and viable mechanism for promoting and protecting human rights, it needs to be something more.

Vaá suggests a way forward when he notes that the concept of human rights contained in the UDHR is foreign to Samoan ways of thought. According to Vaá: ${ }^{36}$

Whereas modern European notions of human rights derive from Christian theological principles, such as those spelt out in Thomas Aquinas's Theory of Natural Rights, and the libertarian and egalitarian principles, such as those stated in the United Nations Universal Declaration of Human Rights 1948, the equivalent ideas in Samoa emanate from custom.

As one Pacific scholar has commented, "why should the Pacific have a human rights mechanism? Whose assumption is this? If it is the Pacific Islands' idea then great, go ahead." 37

here. We simply note that the term is complex and often contextual. Within the Pacific, as elsewhere, particular issues around indigeneity vary in different contexts. We hope that the contexts in which we use the term in this article assist in understanding.

31 AH Angelo "Lo Bilong Yumi Yet" in Essays and Documents on Human Rights in the Pacific (Victoria University Press, Wellington, 1992) 33.

32 International Covenant on Civil and Political Rights (16 December 1966) 999 UNTS 171 [ICCPR].

33 International Covenant on Economic, Social and Cultural Rights (16 December 1966) 993 UNTS 3 [ICESCR].

34 Thaman, above n 18, 2.

35 See discussion in R Crocombe Asia in the Pacific Islands Replacing the West (IPS Publications, Fiji, 2007).

36 U Vaá "Samoan Custom and Human Rights: An Indigenous View" in this volume.

37 K Hay "A Pacific Human Rights Mechanism: Specific Challenges and Requirements" in this volume. 
Of particular note in this context is the initiative of the LAWASIA organisation in the late 1980s. LAWASIA, a private organisation of individuals and law firms in the Asia Pacific region, proposed a draft Pacific Charter of Human Rights. ${ }^{38}$ Jalal notes that in addition to political and social reasons why PICTs did not support earlier attempts to establish a PRM: ${ }^{39}$

Most importantly the initiative was perceived to be driven by outsiders and not Pacific Islanders ... this

is a salutary warning to all of us here, that if this initiative is seen to be driven by outsiders, no matter

how well intentioned or sensitive to Pacific Islanders and their concerns, the initiative will fail.

Colonial history can also not be overlooked. The legacy of Government policies and practices have systematically disadvantaged and oppressed indigenous peoples. ${ }^{40}$ In the Pacific constitutional context, Malifa offers the following insight: ${ }^{41}$

The adoption of constitutions in the South Pacific has focussed more on gaining independence from political control than on ensuring the legitimacy of a particular constitution as supreme law which mandates a new beginning.

Mikaere argues that the prime reason for the current status of Māori is colonisation; so why should Māori seek salvation in the principles of law that have been formulated by colonisers? ${ }^{42}$ This is not to reject absolutely any rights-based discourse. Rather, it indicates that it is illogical for indigenous peoples to turn unquestioningly to Western legal concepts for answers to problems that have been brought into their lives by the imposition of Western law. These past historical injustices ${ }^{43}$ strongly suggest that the starting-point for the PRM should be an indigenous one.

More recent post-colonial events also suggest the importance of an indigenous starting-point. On 13 September 2007, the United Nations General Assembly adopted the Declaration on the Rights of Indigenous Peoples (DRIP). ${ }^{44}$ DRIP is the most important, comprehensive and

38 See "Appendix 1: Report on a proposed Pacific Charter of Human Rights prepared under the auspices of LAWASIA, May 1989" (1992) 22 VUWLR 99.

39 Jalal, above n 4.

40 See D Williams Te Kooti Tango Whenua (Huia Publishers, Wellington, 1999) for discussion of the successive Native Land Acts and alienation of Māori land.

41 T Malifa "The Rights Conflict in the Constitutions of the South Pacific: Seeking Toleration into the $21^{\text {st }}$ Century" in N Tomas (ed) Collective Human Rights of Pacific Peoples (International Research Unit for Māori and Indigenous Education, University of Auckland, Auckland, 1998) 119.

42 A Mikaere "Collective Rights and Gender Issues: A Māori Women's Perspective" in N Tomas (ed) Collective Human Rights of Pacific Peoples (International Research Unit for Māori and Indigenous Education, University of Auckland, Auckland, 1998) 79.

43 See discussion on decolonisation and calls for independence of Pacific nations in Wickliffe, above n 2, 153.

44 Declaration on the Rights of Indigenous Peoples UNGA Res 61/295 (13 September 2007) UN Doc A/RES/61/295. 
progressive international instrument to address indigenous peoples' rights within the international human rights framework. As a declaration, DRIP is not legally binding on states ${ }^{45}$ but is important as a standard-setting document for states and indigenous peoples. Although Australia and New Zealand had been deeply involved in various phases of the drafting over the years, both countries, along with Canada and the United States, voted against adoption of the Declaration. The voting of PICTs was also disappointing. Only the Federated States of Micronesia voted in favour of DRIP. Samoa abstained, and the remaining PICTs were absent. ${ }^{46}$

In light of both colonial and more recent events, we agree with Sir Paul Reeves that: ${ }^{47}$

We must build human rights on the foundation of our own cultural heritages. Human rights law is something that belongs to Pacific peoples because it arises from within our contextual frameworks and reflects our experiences.

In our opinion, culture provides a lens through which any investigation, understanding and debate on human rights should proceed. According to Vaá, human rights in Samoa "do not exist by themselves but are embedded in the culture and are attached to social action." 48 Adopting this approach will assist to ensure any sensitivities to culture are prioritised. We suggest that it is through the lens of Pacific peoples that any such mechanism should be developed. This in itself does not exclude future engagement with the international human rights framework, but it recognises and affirms the standing of Pacific peoples and the unique nature of the Pacific region.

\section{B Participation}

Once an indigenous starting-point is established, in our opinion, each Pacific nation, and civil society from each nation, should fully participate in the development of the PRM. Hay is of the view that "[t]here is an understandable need for a majority of Pacific states to be in support of the

45 S Errico "The UN General Assembly adopts the Declaration on the Rights of Indigenous Peoples" ASIL Insight (2007) 10 (19) 1 www.asil.org/insights/2006/08/insighths060814.html (accessed 31 May 2008). See also J Anaya Indigenous Peoples in International Law (2 ed, Oxford University Press, New York, 2004) 6172 , for arguments that declarations can reflect customary international law.

46 Department of Public Information, United Nations "General Assembly Adopts Declaration on Rights of Indigenous Peoples; "Major Step Forward" towards human rights for all, says President" (13 September 2007) Press Release www.un.org/Newz/Press/docs/2007/ga10612.doc.htm (accessed 24 August 2008).

47 P Reeves "Collective Human Rights of Pacific Peoples" in N Tomas (ed) Collective Human Rights of Pacific Peoples (International Research Unit for Māori and Indigenous Education, University of Auckland, Auckland, 1998) 12.

48 Vaá above n 36. 
development of a regional human rights mechanism if it is to have any chance of success." 49 Further: 50

To advance the concept of a regional human rights mechanism it will be critical for both political and civil society actors to not only support its developments but be involved in the processes that determine the institutional arrangements.

In order to secure support for the PRM, meaningful participation is key. Wickliffe also identified that all Pacific peoples should be represented in all forums to discuss and ultimately implement a PRM. ${ }^{51}$ If each Pacific nation participates and is instrumental in developing the PRM this would arguably induce a wider co-operation. Boyle states that: ${ }^{52}$

In the context of the Pacific region it is important to underline that a regional human rights mechanism needs to have the co-operation of states and an intergovernmental institution within which the mechanism operates. What above all is needed is the political will of states to agree to such a mechanism, to fund it and to implement its decisions or recommendations.

A particular issue is whether Australia and New Zealand should be involved in the development of the PRM. One of the concerns raised by Jalal was: ${ }^{53}$

My primary focus is on Pacific Island countries and territories ... Australia and New Zealand each have well functioning institutions and for practical reasons should not be included in the initial regional mechanism although options for them to join later should be made available.

One of the underlying reasons we suggest an indigenous Pacific lens stems from concern as to the continuing effects of colonisation. We, too, are concerned that any mechanism adopted is not, in either perception or reality, received as a neo-colonial imposition by Australia or New Zealand. However, if an indigenous Pacific lens is adopted right from the outset, then this should assist to allay any anxiety that the involvement of Australia and New Zealand will produce a neo-colonial overtone.

In our view, it is especially important that indigenous Australians and New Zealanders be able to participate in the development of the PRM. As noted above, both New Zealand and Australia voted against the adoption of DRIP. This illustrates how out of step New Zealand and Australia have become with the international community on indigenous issues. This is an added reason why

49 Hay, above n 37.

50 Ibid, 15 .

51 C Wickliffe "Human Rights Education in the Pacific" (1999) 3 Journal of South Pacific Law, Working Paper 1 available at www.vanuatu.usp.ac.fj (accessed 15 May 2008).

52 K Boyle "The European Experience: The European Convention on Human Rights" in this volume.

53 Jalal, above n 4, 2-3. 
there should be participation by New Zealand and Australian Indigenous groups. The DRIP experience and the Māori experience with the Foreshore and Seabed Act 2004 highlight the need to adopt an indigenous starting-point for any proposed PRM. This will require strong leadership from within the Pacific community and commitment to ensuring human rights and custom are compatible.

\section{Human Rights Education}

The third procedural building block which we see as important to ensure a culturally legitimate, robust and viable PRM is human rights education. As Thaman noted ten years ago, "[h]olistic human rights education, both formal and non-formal, will be a necessary ingredient of any human rights awareness initiative in the region." ${ }^{54}$ Further, according to Wickliffe: ${ }^{55}$

Some attempt to harmonise principles of the Pacific cultures with the need to promote and protect human rights must be made. This will only be achieved through good human rights education.

There are two time-frames of relevance. First, as any PRM is developed, human rights education is a necessary adjunct to ensuring sound participation (discussed above), and engendering culturally legitimate substantive content of any mechanism (discussed below). Secondly, human rights education is ongoing and so will continue to be important once the PRM is adopted and implemented.

Within the international human rights framework, human rights education is sometimes seen as a right in and of itself, based on the requirement in the United Nations Charter for states to promote and encourage respect for human rights. ${ }^{56}$ The aim is to ensure that people are aware of their rights in order that they can exercise them. A related element is ensuring that officials in the legislative, executive and judicial branches of government are also aware of human rights so that their laws, policies, practices and judgments are in conformity with human rights.

In order for human rights education to succeed, it needs to be tailored to the local cultural context. This is important because otherwise there is a risk that the zeal of human rights advocates in enthusiastically promoting human rights will undermine the palatability of their message. To avoid this risk, human rights education needs to meet the requirements of the particular audience. The success of human rights education about the PRM will depend in large part on the extent to which the PRM is seen as owned by the peoples of the Pacific.

54 Thaman, above n $18,9$.

55 Wickliffe, above n 2.

56 See for example Rhona K M Smith Textbook on International Human Rights (Oxford University Press, Oxford, 2007) 297. 
Our view of human rights education is however broader than simply tailoring the human rights message to the local culture. We are concerned not only with training, dissemination and information efforts. We conceive of human rights education as being something more dynamic and collaborative. In our view, the aim of human rights education should go beyond dissemination of information about human rights and contribute to achieving a "cultural synthesis" that makes human rights "right" for Pacific peoples. ${ }^{57}$ One commentator has noted that perhaps the flaw in the LAWASIA initiative was that not enough space or resources were provided to ensure that Pacific peoples could internalise and own the discourse of human rights. ${ }^{58}$

Culture is significant here. Culture can be a barrier or the key to embedding a human rights culture in the Pacific. According to Wickliffe: ${ }^{59}$

There is a need to advance the discussions on human rights in the Pacific by illustrating the relevance of human rights and values to all Pacific peoples. As culture pervades the entire way of life of all Pacific peoples, [culture] is the answer to promoting respect for human rights and advancing the Universal

Declaration of Human Rights as a common standard.

Thaman suggests that in order for human rights to be understood by and acceptable to Pacific Island communities, it must take into account the value contexts and cultural perspectives of those communities. ${ }^{60}$ Thaman also reminds us that Pacific culture is not monolithic. Therefore, culture should be used to investigate, question and understand existing and proposed human rights standards in order to ensure that the sensitivities which Pacific states seek from the international community are accorded to the different cultural communities in their own countries. ${ }^{61}$

These ideas are echoed by scholars such as Sally Engle Merry. Merry suggests that the debate between universalism and relativism is premised on a fixed and abstract conception of both culture and rights, but that in fact both concepts are fluid and changing. She describes the struggle of women human rights activists in the Solomon Islands seeking to create a space which incorporates both cultural differences and transnational conceptions of human rights. The aim of such activists is to attain the strength of the international rights framework, without its individualising, Western implications and alienation from their own local cultural understandings. ${ }^{62}$

57 Thaman, above n 18, 9.

58 Wickliffe, above n 51, 6.

59 Ibid, 7.

60 Thaman, above n 18, 4.

61 Ibid, 8 .

62 Sally Engle Merry "Changing rights, changing culture" in Jane K Cowan, Marie-Benedicte Dembour and Richard A Wilson (eds) Culture and Rights: Anthropological Perspectives (Cambridge University Press, Cambridge, 2001) 31-32. 
We suggest that a similar aim is likely to be relevant as the PRM is drafted and implemented, particularly in the context of human rights education. We, too, believe in, on the one hand, the capacity of the human rights system to adapt to the cultural context, and, on the other hand, the potential for culture and custom to be enhanced by human rights. Each one can, and should, inform the other. In our view, human rights education in support of the PRM should be undertaken in this context. Not only should human rights education enable dissemination of knowledge about the international human rights framework and the PRM, but human rights education should also "provide opportunities for Pacific peoples to develop a regional philosophy of rights and responsibilities." 63

\section{SUBSTANTIVE BUILDING BLOCKS}

Jalal states that: ${ }^{64}$

The Charter should reinforce the universal rights established by international human rights instruments but should also be expanded to recognise rights and duties that are peculiar to PICTs. In giving recognition to these rights and duties, care should be taken to ensure that they do not conflict with or whittle down universal rights.

In our view, there are two key substantive issues which, taking into account the Pacific cultural context, need to be considered in the development of the PRM - group rights and duties. While it will be challenging to incorporate both of these without whittling down universal rights, in our view, both should be aimed for as they are likely to be essential in ensuring cultural legitimacy of the mechanism.

\section{A Group Rights}

A basic tenet of indigeneity is the concept of the collective. Pacific and indigenous cultures are defined by their culture and underpinned by a collective or group ethic set on a framework of whakapapa (genealogy, cultural identity) and the related interconnectedness between all humans and the environment. This underpinning ethic is central to a Māori world-view. The world-view of indigenous peoples is noted as: ${ }^{65}$

[A] distinctive view of reality, which not only interprets and orders the places and events in the experience of a people, but lends form, direction, and continuity of life as well. World view provides people with a distinctive set of values, an identity, a feeling of rootedness, of belonging to a time and place, and a sense of community with a tradition which transcends ... even time.

63 Wickliffe, above n 51,7 .

64 Jalal, above n 4, 7.

65 A Ortiz "Look to the Mountain Top" in E G Ward (ed) Essays in Reflection (Houghton-Mifflin, Boston, 1973) 91. 
The concept of the collective is not well understood by Pakeha lawmakers and has not traditionally played a prominent role in the international human rights framework which tends to reflect an individualistic approach, such as is evident in the UDHR. ${ }^{66}$ Thaman was critical of LAWASIA's Pacific Charter: ${ }^{67}$

The draft Pacific Charter ... is still very much a European document and there is still concern in some quarters that attempts to contextualise it in order to reflect collective rights may be abused if people (meaning groups) don't understand the basis for these collective rights.

The international human rights framework is, however, increasingly beginning to recognise group rights and human rights of indigenous peoples. ${ }^{68}$ DRIP explicitly provides that indigenous peoples have the right to full enjoyment of all human rights and fundamental freedoms "as a collective or as individuals." 69 Collective rights recognised in DRIP include the right to selfdetermination, ${ }^{70}$ the collective right to live in freedom, peace and security as distinct peoples, ${ }^{71}$ and the right to practice and revitalise cultural traditions and customs. ${ }^{72}$ Some domestic constitutions also recognise group rights. The Constitutions of the Federated States of Micronesia ${ }^{73}$ and Fiji ${ }^{74}$ both expressly recognise group-based customary law rights. The Draft Federal Constitution of the Solomon Islands 2004 includes a number of provisions that expressly recognise the rights of clans and tribal village communities including rights to maintain and develop their laws and customary practices and to pursue their economic development. ${ }^{75}$

In our view, it is important that the PRM recognise core values intrinsic to indigenous Pacific cultures such as the importance of the collectivity. There are two aspects to recognition of group rights. First, the recognition of rights of groups themselves. The precise content of these will be determined as the PRM is developed. However, the examples given above from DRIP and the Draft Federal Constitution of the Solomon Islands may provide a useful starting point.

66 J Patterson Exploring Māori Values (The Dunmore Press, Palmerston North, 1992) 136.

67 Thaman, above n 18, 3 .

68 New Zealand Law Commission, above n 28, paras 14.55-14.57.

69 Declaration on the Rights of Indigenous Peoples, above n 44, Art 1.

70 Ibid, Art 3.

71 Ibid, Art 7(2).

72 Ibid, Art 11(1).

73 Constitution of the Federated States of Micronesia 1979, Art V.

74 Constitution of Fijian Islands 1997, chapter 13.

75 Draft Federal Constitution of the Solomon Islands 2004, cls 21(1)(b), 41, 49 and 50. 
Group rights can not only be recognised in and of themselves, but can also inform interpretation and implementation of "individual" rights. This second aspect of group rights enables culturally influenced forms of implementation of basic rights such as the right to a fair trial. ${ }^{76}$ For instance, in New Zealand the marae is sometimes used as a suitable forum to deal with Māori offenders. ${ }^{77}$ This is known as "marae justice" where responsibility is focussed upon the collective rather than the individual in a setting that is culturally consistent with tikanga Māori and kaupapa Māori.

Due process and procedural fairness involve the principle that the Government respects all of a person's legal rights (including tikanga) instead of just some or most of those legal rights when the government deprives a person of life, liberty, or property. So the right of an individual to seek a fair trial, declared in the UDHR, may, in some contexts require the consideration of a cultural element to satisfy procedural fairness. In this instance, for Māori, a fair trial may require a hearing on a marae.

There are similar experiences around the Pacific. In Samoa, consideration of cultural elements such as ifoga is required for procedural fairness. Samoan courts take into consideration ifoga during sentencing as a mitigating factor and in many instances the prescribed sentence is reduced. ${ }^{78}$ This consideration of a culturally specific custom is at the discretion of the courts. In Tonga, although the Constitution does not explicitly recognise custom, an academic commentator has observed that in criminal proceedings, the hearing, charges and issues are usually framed and discussed in terms of Tongan custom and the obligations arising from significant village relationships. ${ }^{79}$ Similarly, in Australia, for Indigenous Australians, legislation directs consideration of indigenous sentencing practices. The Magistrates (Koori Court) Act 2002 provides for the establishment of a Koori Division of the Magistrates Court and defines the jurisdiction and procedure of the Koori Division. Notably, Australian jurisdictions that have established Koori Courts to deal with sentencing of Aboriginal peoples have yielded far lower recidivism rates. ${ }^{80}$

In our view, the idea of group rights merits careful consideration as the PRM is developed. Both the notion of stand-alone group rights and the separate notion of interpreting and applying individual rights in their collective context are worthy of further consideration.

76 UDHR, above n 3, Art 10.

77 See Ministry of Justice Report discussing marae justice and the incorporation of tikanga Māori into the judicial process available at www.justice.govt.nz/pubs/reports/2003/seeking-solutions-hui-july-2003/section -3.html (accessed 31 July 2007).

78 For a recent discussion of the authorities, see Attorney-General v Matalavea [2007] WSCA 8; CA 05/2006 (14 September 2007).

79 S U Philips "The Organization of Ideological Diversity in Discourse: Modern and Neo Traditional Visions of the Tonga State" (2004) 31 American Ethnologist 231.

80 See M Harris A Sentencing Conversation: Evaluation of the Koori Courts Pilot Program October $2002-$ October 2004 (Victorian Department of Justice, March 2006) 15 www.justice.vic.gov.au/wps/wcm/connect/ DOJ+Internet/resources/ (accessed 31 May 2008). 


\section{B Duties}

A second substantive matter that is likely to be necessary to ensure a culturally legitimate, robust and viable PRM is the inclusion of the duties of individuals as well as their rights. The human rights framework is primarily concerned with the rights of individuals and the duties of states to guarantee those rights. There is, however, an identifiable Pacific concern that the singular focus of the human rights movement on individuals develops excessive individualism and is detrimental to societal cohesion. Bernard Narokobi, a leading Papua New Guinean statesman and scholar expresses his concern: ${ }^{81}$

Human rights without effective social obligations are a curse on our lands. Human rights, at least in
Papua New Guinea, have become 'laik bilong wan-wan' - the 'wish of the individual.' The overall impact
of human rights on our societies has become one of self-destruction. We give to ourselves the right to be
lazy, steal, rape, commit adultery, disobey legitimate authority, ignore those in need, abuse our elders,
debase our cultures, exploit our own people, keep them in perpetual serfdom, blaspheme, commit
sacrilege against our ancestors and against God.

The Pacific concern mirrors an international concern at the consequences of excessive individualism. Two recent initiatives are of particular note. In 1997, the Inter Action Council (IAC) proposed a Universal Declaration of Human Responsibilities. The IAC noted its concern that "exclusive insistence on rights can lead to endless dispute and conflict." 82 It sought to balance individual freedom with individual responsibility and in so doing promote "a move from the freedom of indifference to the freedom of involvement." 83

The second international initiative concerning duties built on the IAC's initiative. In 2003, the Commission on Human Rights released the final report of Special Rapporteur Miguel Alfonso Martinez on human rights and human responsibilities. ${ }^{84}$ In his report, Martinez noted that there was a "North-South" polarisation on the issue of duties, with developed countries of the North opposing the formal recognition of any correlation between rights and responsibilities and those of the underdeveloped South acknowledging the important connection between the two. ${ }^{85} \mathrm{He}$ also stated his view that in order to advance further in the field of human rights, it was necessary to create and

81 Bernard Narokobi Lo Bilong Yumi Yet: Law and Custom in Melanesia (Melanesian Institute for Pastoral and Socio-Economic Service and the University of the South Pacific, Suva, 1989) 137.

82 Inter Action Council "A Universal Declaration of Human Responsibilities" (1 September 1997) Introductory Comment.

83 Ibid.

84 UN Commission on Human Rights "Final Report of the Special Rapporteur, Miguel Alfonso Martinez, on the Study requested by the Commission in its resolution 2000/63, and submitted pursuant to Economic and Social Council decision 2002/277" (17 March 2003) E/CN 4/2003/105.

85 Ibid, para 13. 
develop a new individual and collective awareness of the need to find a solid balance between the rights of the individual and his or her social responsibilities. ${ }^{86}$ Special Rapporteur Martinez's report annexed a "Pre-Draft Declaration on Human Social Responsibilities" but this did not proceed any further through the United Nations system.

If it was agreed that the PRM should recognise an individual's duties as well as their rights, the question arises as to what type of duties it might be appropriate to recognise. While this is a matter requiring considerable further work in order to reflect Pacific values, some preliminary comments can be made. Although, as noted above, the international human rights framework is primarily concerned with the rights of individuals and not their duties, it does, when one looks closely, contain some recognition of duties. For example, the preamble to the UDHR provides that "every individual and every organ of society ... shall strive by teaching and education to promote respect for these rights and freedoms." Paragraph 5 of the Preamble to both ICCPR and ICESCR provides that "...the individual, having duties to other individuals and to the community to which he belongs, is under a responsibility to strive for the promotion and observance of the rights recognised in the present Covenant."

Individual duties are sometimes recognised implicitly in the context of particular rights. For example, in the context of the right to freedom of expression, ICCPR article 19(3) provides that the exercise of the right to freedom of expression "carries with it special duties and responsibilities." More broadly, article 29(1) of the UDHR provides that "[e]veryone has duties to the community in which alone the free and full development of his personality is possible."

The human rights treaty with the most extensive recognition of duties is the African Charter on Human and Peoples' Rights (the Banjul Charter). ${ }^{87}$ The Banjul Charter, with its emphasis on the collective and community as well as the individual, is of particular interest in the Pacific context. Three articles set out the duties of individuals. Article 27(1) provides that "[e]very individual shall have duties towards his family and society, the State and other legally recognised communities and the international community." Article 27(2) concerns how an individual is to exercise his or her rights and provides that rights are to be exercised "with due regard to the rights of others, collective security, morality and common interest." Article 28 requires the individual to "respect and consider his fellow beings without discrimination, and to maintain relations aimed at promoting, safeguarding and reinforcing mutual respect and tolerance." Article 29 lists a number of specific duties. Duties to one's family include the preservation of the harmonious development of the family, respecting one's parents and maintaining them in case of need. Duties to the community and the state include serving the national community by placing one's physical and intellectual abilities at its

86 Ibid, paras 37-40.

87 African Charter of Human Rights (27 June 1981) 1520 UNTS 217. See Jacques Fremont "Legal Pluralism, Customary Law and Human Rights in Francophone African Countries" in this volume. 
service, preserving and strengthening social and national solidarity, and positive African cultural values.

Some domestic constitutions also recognise duties. ${ }^{88}$ An example is the Constitution of Vanuatu 1980, which recognises a number of non-justiciable fundamental duties. ${ }^{89}$ The duties are expressed as being owed to oneself, one's descendants and others, and include the duties to respect and to act in the spirit of the Constitution, including exercising one's rights and participating in the government of Vanuatu. Duties to the nation include actively participating in the development of the national community, safeguarding the national wealth, resources and environment in the interests of the present generation and of future generations, and working in socially useful employment. A parent is required to support, assist and educate their children, including giving them an understanding of their fundamental rights and duties, the national objectives and the culture and customs of the people of Vanuatu. A child is required to respect his or her parents.

There are a number of potential advantages for the PRM to recognise duties. The IAC saw its Universal Declaration of Human Responsibilities as a means of "reconciling ideologies, beliefs and political views that were deemed antagonistic in the past"90 - in essence, greater recognition of responsibilities might assist in addressing some of the cultural relativist concerns with the human rights movement. In the Pacific context, recognition of duties alongside individual rights might serve a similar function in the sense of making adoption of a human rights instrument acceptable to those who worry that human rights is a neo-colonialist enterprise. A related advantage is that individual rights can then be seen in their broader context. Recognising duties alongside rights more clearly recognises cultural values of reciprocity and community and situates the individual within his or her community. Vaá notes that in Samoa, traditional notions of human rights are expressed in the responsibilities and obligations of individuals to their kin, affinal and non-kin groups. ${ }^{91}$ In the customary Pacific context, duties and obligations underpin daily life. ${ }^{92}$ The inclusion of duties alongside rights recognises this, and would give the PRM a distinctive Pacific character.

It has also been noted that inclusion of duties such as the duty to support elderly parents and family members may be of particular use in those states like PICTs which have underdeveloped economies, and no, or limited, social security systems. ${ }^{93}$ A related issue concerns the reach of the

88 See the Papua New Guinea Constitution 1975 Preamble, Cook Islands Constitution 1964, s 64(2) and Draft Federal Constitution of the Solomon Islands 2004, cl 11.

89 Constitution of Vanuatu 1980, Art 7.

90 Inter Action Council, above n 82, Introductory Comment.

91 Vaá, above n 36, 8.

92 New Zealand Law Commission, above n 28, para 14.62.

93 Ziyad Motola "Human Rights in Africa: A Cultural, Ideological and Legal Examination" (1988-1989) 12 Hastings International and Comparative Law Review 373, 403-404. 
state into the lives of individuals. In some customary communities in the Pacific, the state has very little involvement in the lives of individuals. Instead, it is customary leaders who have the primary role in terms of regulating the lives of individuals. Imposing duties on individuals, including customary leaders, to respect the rights of others, may therefore ultimately assist in better protecting the rights of all individuals. A rights framework which fully recognises the roles, rights and responsibilities of the individual, the customary community and the state may better reflect the reality of life in small Pacific communities.

There are however some possible disadvantages if the PRM recognises duties. A major concern is that authoritarian states may use duties to suppress human rights. For example, those who seek to challenge corruption may be seen as breaching their duties to the state. At a community level, individual duties owed to the family or community might be misused in order to maintain power relationships that are unequal and based on duress. ${ }^{94}$ Attribution of duties to individuals within the community according to criteria such as age, sex and hierarchical status may reinforce oppressive structures such as patriarchy. Ultimately, the concern with recognising duties in the rights context is that they will undermine individual rights and detract from the dignity of the individual.

The potential disadvantages of explicitly recognising duties in the PRM must be carefully considered. A PRM which undermined rights by recognition of duties would be a disastrous outcome. However, the potential risks of recognising duties may perhaps be mitigated by explicitly noting, as does the Vanuatu Constitution, ${ }^{95}$ that the duties are to be non-justiciable. Duties could then be used in the context of human rights education - ensuring that individual rights are seen in their wider context. They could also be used as aids to interpretation of rights, or perhaps as the basis of a reporting mechanism monitoring the way in which the notion of a communal ethic is operating in society. ${ }^{96}$

\section{A Binding Mechanism}

One of the major shortcomings of the international human rights framework is its weak enforcement mechanisms. This is illustrated by the Māori experience with the challenge to New Zealand's foreshore and seabed legislation. Despite success in international human rights fora, with no commitment by the domestic Government, there was - in the end - no effective remedy for Māori.

Although the enforcement mechanisms in the international human rights framework are weak, in the regional European human rights system, there are stronger enforcement mechanisms. The

94 International Council on Human Rights Policy Taking Duties Seriously: Individual Duties in International Human Rights Law: A Commentary (International Council on Human Rights Policy, Versoix, 1999) 2.

95 Constitution of Vanuatu 1980, Art 8.

96 See for example the Draft Federal Constitution of Solomon Islands 2004, cl 12(2). 
Convention for the Protection of Human Rights and Fundamental Freedoms, also known as the European Convention on Human Rights (ECHR), ${ }^{97}$ was adopted under the auspices of the Council of Europe in 1950 to protect human rights and fundamental freedoms. All Council of Europe member states are party to the Convention and new members are expected to ratify the ECHR at the earliest opportunity.

The ECHR established the European Court of Human Rights. Since 1998, with the entry into force of Protocol 11 to the ECHR, the individual complaint process became compulsory for all states that are party to the ECHR. Any person who feels their rights have been violated under the ECHR by a state party can take a case to the Court. Procedural requirements before the Court will consider a case include the exhaustion of available domestic remedies. The decisions of the Court are legally binding, and the Court has the power to award damages. The establishment of a judicial mechanism, accessible by individuals, to provide protection from human rights violations is an innovative feature for an international convention on human rights. It gives the individual an active role in the international arena, where traditionally international law only recognised states as actors. The ECHR is still the only international human rights agreement providing such a high degree of individual protection.

In our view, for the PRM to be a robust means of protecting and promoting human rights, it needs to have strong enforcement mechanisms. Ultimately, decisions of the PRM should be binding on member states. Ideally, the PRM would be eventually incorporated into each legal system of member states, and domestic courts would recognise judgments from the PRM. This would minimise the risk of a state ignoring with impunity the considered views of the PRM.

However, such a concession of national sovereignty, especially for PICTs wary of the international human rights movement, may be too great a leap of faith at the outset. We note, however, that there has already been some discussion around the possibility of a general regional Pacific appellate court which may indicate this concern is misplaced. ${ }^{98}$ Nevertheless, small steps may be required before a legally binding mechanism is adopted. A regional human rights commission with recommendatory powers could be an appropriate starting point. A regional commission could itself work with Pacific nations to adopt and develop a legally binding mechanism.

In our view, if an indigenous perspective is adopted and there is effective participation from Pacific nations, then over time, as with the ECHR, it is not unforeseeable that Pacific nations could

97 European Convention for the Protection of Human Rights and Fundamental Freedoms 213 UNTS 221 [ECHR].

98 "Judges support a Pacific Regional Court" www.rrrt.org/page.asp?active_page_id=235 (accessed 30 May 2008); "Regional Pacific Court Mooted" Daily New Zealand News (9 December 2007) http://newszealand.blogspot.com/2007/12/regional-pacific-court-mooted.html (accessed 30 May 2008). 
accept and respect the judgments of the PRM and implement them accordingly. In the long-term, particularly in light of the Māori experience with the international human rights framework over the foreshore and seabed controversy, a mechanism with the power to issue legally binding judgments is a necessary ingredient for a robust PRM.

\section{CONCLUSION}

A Pacific regional human rights mechanism offers huge - and exciting - potential for advancing the cause of human rights in the Pacific. However, the lessons from the negative impacts of past practices and colonisation on Pacific Peoples should not be forgotten. Rather than have the content and scope of a Pacific human rights charter pre-determined by existing understandings of human rights, it is suggested that an indigenous starting point should be adopted. It is through an indigenous lens that any such mechanism should be developed and it is an indigenous starting point that will ultimately ensure a culturally legitimate, robust and viable human rights mechanism for the Pacific.

Using an indigenous lens, this article has suggested some building blocks for the mechanism. In addition to the indigenous lens, two other procedural building blocks are essential. Effective participation of all Pacific nations and civil society within those nations is required. Human rights education, both during the development of the mechanism and once it is operational, and undertaken with a willingness to seek a "cultural synthesis" of rights appropriate for the Pacific context is also important.

We suggest three substantive building blocks which are likely to be important for the cultural legitimacy of the Pacific mechanism. Recognition of group rights in addition to individual rights is likely to be necessary to situate individual rights within their collective context. The possibility of individual duties alongside rights will also require careful consideration. Although the prospect of a legally binding mechanism may seem daunting, in our view, in order to ensure strong protection of rights, decisions from the regional mechanism should be binding. It is, however, acknowledged that small steps may be initially required, with a binding mechanism a longer-term goal. In a perfect world, a Pacific regional human rights mechanism which is truly indigenous is not beyond reach. However, it is acknowledged that the road ahead to achieve a culturally legitimate, robust and viable regional mechanism for the Pacific is not without potholes and deceptive curves. 